ISSN: 2349-2031

Research Article

\title{
Earnings Management and Value Relevance in Nigeria: A Pre and Post Ifrs Analysis
}

\author{
Sunny O. Temile ${ }^{1}$, Al Bahloul Mohammed ${ }^{1}$, Dadang Prasetyo Jatmiko \\ ${ }^{1}$ University of Salford, United Kingdom \\ ${ }^{2}$ Researcher at RISET-Pro, Kemristek- DIKTI, Indonesia
}

\begin{abstract}
The purpose of this article is to analyse the literature concerning legal framework for outer space activities by states. Review was conducted on the elements of national space law, including literature critiquing particular strengths or weaknesses of existing laws and literature, on the obligations placed on States under international law and on why writers make particular recommendations as to the content of legislation. The article will summarise the key elements one would anticipate finding in the outer space regulatory framework and which will form the structure of the analytical framework when considering how States implement international space law in practice. In recent times, the issue of earnings management and value relevance has caused financial reports to come under scrutiny. With the introduction of the International Financial Reporting Standards (IFRS), a lot of studies have been carried out to see what kind of effect it has on key financial variables such as earnings management and value relevance of firms. Therefore, this study, "Earnings Management and Value Relevance in Nigeria: A Pre and Post IFRS Analysis", examined the impact of IFRS on Earnings Management and Value Relevance of financial information in Non-Financial Companies quoted in the Nigerian Stock Exchange (NSE). Data gathered are from the financial statements and annual reports of 60 Companies from the NonFinancial Sector of the Nigeria Stock Exchange because companies in the financial sector are not overall amendable to accruals model. The empirical study covered the period from 2007 to 2016 statistical and econometric tools such as Panel data regression and paired samples tests. The results revealed an increase in value relevance, and a decrease in earnings management in the Post-IFRS era. Thus, we infer that earnings management level has decreased while value relevance has increased since IFRS adoption. This study therefore recommends that the relevant regulatory bodies should be empowered by the government to enable the formulation of effective measures and policies that check earnings management practices, and foster value relevance of the financial information presented in the annual reports and accounts of Nigerian companies.
\end{abstract}

Keywords: Earnings Management, Value Relevance, Financial Sector, Pre \& Post IFRS

\subsection{INTRODUCTION}

With the recent globalization of the international financial markets, there has been a universal agitation for adoption of a common language for financial reporting to enhance international comparability. One of the ways or approaches adopted by Europe and other countries to enhance comparability is to adopt a unified financial reporting language by adopting International Financial Reporting Standard, commonly called IFRS (Jeanjean \& Stolowy, 2008). IFRS is viewed as a financial reporting system supported by strong governance, high quality standards and sound regulatory framework which is key to economic development. Jeanjean and Stolowy (2008) opined that IFRS would enhance the effectiveness of competition for international funds and make international capital markets more efficient, leading to a lower cost of capital for firms. One of the goals of the IASB is to develop an internationally acceptable set of high quality financial reporting standards to meet the criteria of relevance, transparency, reliability and comparability required by the International Accounting Standard regulation. To achieve this goal, the IASB has issued principle-based common standards hoping to remove certain degree of discretion and accounting alternatives to better reflect a firm's economic position and performance (Luz, 2013). Recently, around the world, more than 120 countries and reporting jurisdiction required domestic listed companies to prepare their financial statements in accordance with IFRS (Mousa \& Desoky, 2014). It is also worthy of note that although many countries have made IFRS adoption mandatory, some are still to make it mandatory, while others are considering the IFRS adoption.

By January $1^{\text {st }} 2012$, it became obligatory for all companies quoted in the Nigerian Stock Exchange (NSE) to report their financial details and annual financial reports in accordance with the provisions of IFRS issued by the IASB. Prior to 2012, the Nigerian Generally Accepted Accounting Principles (that is, Statement of Accounting Standards-SAS) issued by the Nigerian Accounting Standard Board -NASB (now Financial Reporting Council of Nigeria-FRCN) was used for financial reporting.

Although, the aim of the IFRS is to provide better and improved financial reports, it is one of management's fundamental responsibilities to provide a high financial reporting quality since they stand at a stewardship position 


\section{Sunny O. Temile et al / Earnings Management And Value Relevance In Nigeria: A Pre And Post Ifrs Analysis}

with the stakeholders of the company. In order to do this, management has to provide reliable and relevant financial information regarding share price, earnings, book value per share and other performance indicators that will help investors' assess and evaluate the company's performance and prospects. The quality of financial information can be assessed by, amongst other things, the incidence of earnings management (Elias, 2012).

There has been a lot of research on with respect to earnings management and value relevance of accounting information (Olayinka, 2012; Jinadu, 2016). Despite the general notion that the adoption and implementation of IFRS improves financial reporting quality and relevance of accounting information, previous research has shown conflicting conclusions as to whether there has been a decrease (or increase) in earnings management and value relevance of financial information since the introduction of the mandatory IFRS by the IASB (Napaporn and Siriluck, 2015; Kaaya, 2015). Another gap in prior literature on this topic is the fact that they were centered on data generated from companies in their IFRS implementation or transition phase. For instance, Capkun, Cazavan-Jeny, Jeanjean and Weiss (2008), concluded that earnings management is present during the transition to IFRS. Also, Callao and Jarne (2010) gave evidence of increase in earnings management after the IFRS adoption in European countries. Cai, Rahman and Courtenay (2008), found that there was a declining earnings management after both voluntary and mandatory adoption of IFRS. Based on these mixed conclusions, this study focusing solely on non-financial companies quoted in the Nigerian stock exchange, contributes to this area of study.

This study will significantly contribute to literature because, all the previous studies relate to a certain time frame and given the ever-changing and active nature of accounting, it becomes necessary to continually fill the gaps of what is known about the level of earnings management and state of value relevance of accounting information in Nigeria; hence the purpose and scope of this study. This research will therefore, through its robust analysis using 60 firms for the period of ten (10) years, assist by providing an in-depth knowledge of the effects of adopting IFRS on the existence of earnings management and the state of value relevance of accounting information. This knowledge can also be used by different stakeholders of the companies that report their financial statements in accordance with IFRS. Investors (existing and potential) will also gain more insight on the value relevance of financial statements and reports for evaluation of companies' performance and prospects and their investment decision. Also, regulators can gain from the results and conclusions of the study since it will be an indication of the extent to which their objectives are achieved.

Secondly, since there are limited up-to-date studies in this area, this study will give readers a clearer, more recent view of the impact of the IFRS on the level of earnings management and value relevance of accounting information in Nigerian quoted non-financial companies.

The remainder of this paper is prearranged as follows: Section two provides empirical background and the hypotheses of the research. More precisely, this paper explores the literature by addressing the potential effects of IFRS on earnings management and value relevance in Nigeria. Section three presents the research methodology. Section four discusses the empirical findings of our study. Finally, conclusion and recommendation are made in section five.

\subsection{LITERATURE REVIEW}

Since the mandatory adoption of IFRS by a lot of countries in the world, a lot of effort has been put in research to determine the effect it has on key variables such as value relevance and earnings management. This section thus reviews the relevant theoretical and empirical literature in connection with the topic under study.

There are generally two views of earnings management. Firstly, it is seen as a management tool used for fulfilling their responsibility of wealth maximization. Secondly, earnings management is considered as an alteration of economic events in order to mislead the users of financial statements. These two different perspectives have led to various definitions of earnings management in prior literature.

On the aspect of earnings management having a positive effect, earnings management is defined by Beneish (2001) as a way for managers to disclose their private expectations about the firm's future cash flows to investors. This was also supported by McKee (2005) who defined earnings as reasonable and legal management decision making and reporting intended to achieve stable and predictable financial results. Fields, Lys and Vincent (2001) were also in support of this view. On the perspective of earnings management having a negative effect, the following definitions are put forth.

Shipper (1989) viewed earnings management as "a purposeful intervention in the external financial reporting process, with the intent of obtaining some private gains, as opposed to say, merely facilitating the neutral operation of the process". Another commonly cited definition was given by Healy and Wahlen (1999): “earnings management occurs when managers use judgment in financial reporting and structuring transactions to alter financial reports to either mislead some stakeholders about the underlying economic performance of the company, or to influence contractual outcome that depends on reported accounting numbers".

Value relevance, on the other hand, is one of the proxies outside earnings management used in measuring financial reporting quality. The earliest study of value relevance of accounting information started with a seminar work by Ball and Brown (1968). Value relevance of accounting information is simply the value which users of financial statements place on them for investment decisions and otherwise. According to Vishnani and Shah (2008), value relevance depicts the ability of accounting information in financial statements to explain how the stock market is measured. It is also the ability of information to capture of affect share value (Barth et al., 2001; Hellstrom, 2009).

The significance of theoretical framework in accounting studies cannot be over-emphasized. According to Neuman 
Sunny O. Temile et al / Earnings Management And Value Relevance In Nigeria: A Pre And Post Ifrs Analysis

(2004), theories contain concepts and assumptions whose relationship is expressed by investigative study. The underpinning theory for this study is the Agency Theory. The separation of ownership from management (control) in modern corporations gave credence to the agency theory. Since ownership is widely dispersed in modern corporations, in form of shareholders, who are not directly involved in the administration and control of the daily operations of their companies, an agent is thus appointed to oversee this function. This separation creates the possibility for conflicts of interest between the agents and principals, which results in cost in connection with the resolution of these conflicts (Jensen \& Meckling, 1976; Eisenhardt, 1989). Musa and Shehu (2014) suggested that management (agents) have better access to company's financials which can be communicated to the market in order to enhance the firm's value. Through this medium of financial reporting, management provides accounting information to the users of these information for informed judgment and decisions. Because of the information asymmetry that exists, management is motivated by their own person gains rather that of the shareholders and maximization of shareholders' value. As a result, management usually have incentives to manage the firm's financial reports in order to meet earnings targets. They thus exercise their discretion on accrual, which eventually reduces the relevance and reliability of reported earnings, and the entire financial statements.

Therefore, the dilemma denoted by the agency theory can only be resolved by ensuring that the shareholders' interest is pursued rather than that of the management for their own benefits. Fama and Jensen (1983) suggested that firms should employ a system that can separate decision management from decision control if agency costs caused by the separation of ownership from control are to be effectively limited.

\subsection{Empirical Review of the Impact of IFRS on Earnings Management}

Numerous studies have investigated the impact of IFRS adoption on earnings management but there is no general consensus on the kind of impact it has.

Cai et al. (2008) reported a declining earnings management after the voluntary and obligatory IFRS adoption from his study of 32 countries from 2000 to 2006. Barth et al. (2008) who studied 21 countries reported decreasing earnings management, more value relevance of accounting information and timely loss recognition during the post IFRS adoption period. This result was also supported but Christensen, Lee and Walker (2008), that earnings management declined and timely loss recognition increased after IFRS adoption in Sweden and Germany. Thus, their findings stipulate that companies that adopt a higher quality international financial reporting framework would eventually have a higher financial reporting quality.

Ashbaugh, LaFond and Mayhew (2003) who examined 17 European nations identified decreasing earnings management and they maintained that IFRS requires higher information disclosure which enhances manipulation risk of being detected, hence boosting the cost associated with earnings management.

Yahaya, Kutigi and Mohammed (2015) investigated the impact of IFRS adoption on earnings management behaviours of listed deposit money banks in Nigeria. They reported that the restriction to incur losses under IFRS substantially reduces the banks' ability to engage in earnings management.

In contrast to the above positive effects of IFRS adoption on earnings management, some researchers disagrees and concluded that IFRS has a rather negative effect or no effect of any sort on earnings management. They also argued that earnings management practices have rather intensified since the adoption of IFRS. A study by Callao and Jarne (2010) suggested that IFRS have actually stimulated discretionary accounting and opportunistic behaviour in some nations, possibly resulting from institutional and environmental factors and country specific characteristics. Other researchers in support of the negative impact of IFRS on earnings management includes amongst others Jeanjean and Stolowy (2008); Li and Park (2012); Rudra and Bhattacharjee (2012). Based on these, we frame our first hypothesis in its null form thus:

$\mathbf{H o}_{1}$ : There is no significant relationship between IFRS option and the level of earnings management in Nigeria.

\subsection{Empirical review of the impact of IFRS on value relevance}

Studies on the impact of IFRS on value relevance have been carried out on firms in both developed and developing countries and yielded different results.

In a study of German firms, Bartov, Goldberg and Kim (2005) reported enhancement of accounting information quality for companies adopting IFRS. Clarkson, Douglas, Richardson and Thompson (2011) analysed European and Australian firms to ascertain whether the adoption of IFRS has significantly impacted value relevance of book value and earnings. In contrast, studies by Kargin (2013) in Turkey; Gaston, Garcia, Jarne and Gadea (2010) in UK and Spain; Tsalavoutas, Andre and Evans (2012) in Greece; and Callao, Jarne and Lainez (2007), reported otherwise. They were of the opinioned that value relevance did not improve with the adoption of IFRS in the regions concerned. Chunhui, Yao, Lee and Liu (2011) tested the effects of adopting IFRS on the value relevance of earnings in China. They revealed significant improvement in the quality of earnings under IFRS. Vijitha and Nimalathasan (2013) revealed significant impact of value relevance of financial information on share value at the Colombo Stock Exchange in Sri Lanka. These results were also in line with Kamath and Desai (2014) from the Indian context.

Inconsistent with the above conclusions, some other empirical studies revealed a negative impact of IFRS adoption on value relevance of accounting amounts and information (Paananen, 2008 for Sweden; Lin \& Chen, 2005 for China).

In light of the foregoing, we state the second hypothesis of the study below;

$\mathbf{H}_{\mathbf{O} 2}$ : There is no significant influence of IFRS adoption on value relevance of accounting information. 
In Nigeria, the largest emerging nation in Sub-Saharan Africa has also had her own taste of value relevance literature. Some of such empirical studies conducted in the Nigerian context on value relevance are: Adebimpe and Ekwere (2015); Umoren and Enang (2015); Adaramola and Oyerinde (2014); Omokhudu and Ibadin (2015).

\subsection{RESEARCH METHODOLOGY}

This study is of an observational nature which employs the cross-sectional survey and longitudinal survey research design. The population of this study consists of all 172 firms quoted on the Nigerian Stock Exchange as at 31st December, 2017. The sample for this study consists of 60 companies from the non-financial sector quoted in the Nigerian Stock Exchange. This sample is based on the availability and accessibility of corporate annual reports of the companies for the period under study. The sampling technique for this study is the Convenience sampling technique which is a nonprobabilistic sampling method.

Secondary data will be used for this study. Data will be sourced from published Corporate Annual Reports and Stock Prices gathered from the Nigerian Stock Exchange's website, covering the period from 2007 to 2016 financial years. This would entail five years before and after the mandatory adoption of IFRS for quoted firms in Nigeria respectively, that is, Pre-period (2007-2011) and Post period (2012-2016).

The Modified Jones Model (1995) will be used for earnings management measurement. The model for earnings management is given as:

$\mathrm{TA}_{\mathrm{it}} / \mathrm{A}_{\mathrm{it}-1}=\left(\Delta \mathrm{CA}_{\mathrm{it}}-\Delta \mathrm{CL}_{\mathrm{it}}-\Delta \mathrm{CASH}_{\mathrm{it}}+\Delta \mathrm{STD}_{\mathrm{it}}-\Delta \mathrm{DEP}_{\mathrm{it}}\right) / \mathrm{A}_{\mathrm{it}-1---\cdot-}$ (1)

Where; $\mathrm{TA}_{\mathrm{it}}=$ Total accruals in year $t$ for firm $i$

$\mathrm{A}_{\mathrm{it}-1}=$ Total assets at $t-1$ for firm $i$

$\Delta \mathrm{CA}_{\mathrm{it}}=$ Change in current assets

$\Delta \mathrm{CL}_{\mathrm{it}}=$ Change in current liabilities

$\Delta \mathrm{CASH}_{\mathrm{it}}=$ Change in cash and cash equivalents

$\triangle \mathrm{STD}_{\mathrm{it}}=$ Change in debt included in current liabilities

$\Delta \mathrm{DEP}_{\text {it }}=$ Change in depreciation, depletion and amortization expenses

Discretionary Accruals (DA) is determined as the residual (difference) between TA and NDA as follows:
$\mathrm{DA}_{\mathrm{it}} / \mathrm{A}_{\mathrm{it}-1}=\mathrm{TA}_{\mathrm{it}} / \mathrm{A}_{\mathrm{it}-1}-\left[\beta_{0}+\beta_{1}\left(1 / \mathrm{A}_{\mathrm{it}-1}\right)+\beta_{2}\left(\Delta \mathrm{REV}_{\mathrm{it}}-\right.\right.$ $\left.\left.\Delta \mathrm{REC}_{\mathrm{it}} / \mathrm{A}_{\mathrm{it}-1}\right)+\beta_{3}\left(\mathrm{PPE}_{\mathrm{it}} / \mathrm{A}_{\mathrm{it}-1}\right)+\varepsilon_{\mathrm{it}}\right]---(2)$

Thus,

$\mathrm{DA}_{\mathrm{it}} / \mathrm{A}_{\mathrm{it}-1}=\left[\mathrm{TA}_{\mathrm{it}} / \mathrm{A}_{\mathrm{it}-1}\right]-\left[\mathrm{NDA}_{\mathrm{it}} / \mathrm{A}_{\mathrm{it}-1}\right]$

Where;

$\mathrm{DA}_{\mathrm{it}}=$ Discretionary accruals in year $t$ for firm $i$

$\mathrm{A}_{\mathrm{it}-1}=$ Total assets at $t-1$ for firm $i$

$\mathrm{TA}_{\mathrm{it}}=$ Total accruals in year $t$ for firm $i$

$\mathrm{NDA}_{\mathrm{it}}=$ Non-discretionary accruals in year $t$ for firm $i$

(All variables are scaled by lagged total assets to make it possible to compare firms of different sizes and over time).

Note: The discretionary accruals estimate for the firm is based on the total accruals, that is, a residual. The primary aim of regressing model (2) is to be able to generate discretionary accruals which is fundamental in earnings management analysis.

For value relevance, this study adopts the Price model as given by Ohlson (1995), which provides a relationship between capital market variables and accounting variables. The model for this study is specified thus;

$\mathrm{SP}_{\mathrm{it}}=\beta_{0}+\beta_{1} \mathrm{EPS}_{\mathrm{it}}+\beta_{2} \mathrm{BVPS}_{\mathrm{it}}+\varepsilon_{\mathrm{it}}$

Where;

$\mathrm{SP}_{\mathrm{it}}=$ Stock price (market value) at fiscal year

$\mathrm{EPS}_{\mathrm{it}}=$ Earnings per share of firm $i$ in year $t$

$\mathrm{BVPS}_{\mathrm{it}}=$ Book value of equity per share of firm $i$ in

year $t$

$\varepsilon_{\mathrm{it}}=$ Error (stochastic) term in year $t$ for firm $i$

$\beta_{0}, \beta_{1}$ and $\beta_{2}=$ Firm-specific parameters

This study will adopt the Panel Least-Square Regression analysis as the econometric tool for determination of impact of IFRS adoption on value relevance for the study periods, while a paired sample t-test will be used to observe the effect of IFRS on earnings management. The study has also employed the Pearson's Correlation Coefficient technique to determine the relationships between the variables of the study.

\subsection{DISCUSSION OF RESULTS}

This section of the study is committed to presentation of the results from the estimation of the specified model. This will be done using both descriptive statistics and empirical analysis

Table 4.1 Descriptive Statistics

\begin{tabular}{|c|c|c|c|c|c|}
\hline Variable & $\mathbf{N}$ & Minimum & Maximum & Mean & $\begin{array}{c}\text { Std. } \\
\text { Deviation }\end{array}$ \\
\hline 1/A $A_{T-1}$ PRE IFRS & 300 & -3.0900 & 8.8300 & 0.178033 & 0.7563138 \\
\hline TA PRE IFRS & 300 & -124.9314 & 4.0935 & -0.524500 & 7.6584768 \\
\hline NDA PRE IFRS & 300 & 0.0000 & 124.8118 & 1.160460 & 7.6974822 \\
\hline DA PRE IFRS & 300 & -.0049 & .0173 & .000154 & .0012119 \\
\hline SP PRE IFRS & 300 & 0.2000 & 445.6600 & 26.660927 & 54.6252224 \\
\hline BV PRE IFRS & 300 & -49.8971 & 23.4547 & 0.053177 & 3.4724451 \\
\hline EPS PRE IFRS & 300 & -542.9300 & 2019.0000 & 93.371004 & 227.5307932 \\
\hline & & POST & IFRS & & \\
\hline
\end{tabular}


Sunny O. Temile et al / Earnings Management And Value Relevance In Nigeria: A Pre And Post Ifrs Analysis

\begin{tabular}{|l|r|r|r|r|r|}
\hline 1/A $\mathbf{A}_{\text {T-1 }}$ POST IFRS & 300 & -6.9200 & 1.1500 & -0.005667 & 0.5068335 \\
TA POST IFRS & 300 & -1.1854 & 56.0409 & 0.176554 & 3.2409433 \\
NDA POST IFRS & 300 & 0.0000 & 963.7000 & 3.671367 & 55.6136771 \\
DA POST IFRS & 300 & -0.0065 & 0.0143 & 0.000109 & 0.0010452 \\
SP POST IFRS & 300 & 0.5000 & 1200.0000 & 38.804567 & 127.0384248 \\
BV POST IFRS & 300 & -16.2242 & 180.4543 & 0.982855 & 10.7323998 \\
EPS POST IFRS & 300 & -2076.0000 & 4011.8702 & 92.115477 & 360.0403475 \\
\hline
\end{tabular}

Source: Author's Compilation (2018)

Table 4.1 presents the general characteristics of Earnings management and Value relevance indicators/variables. For the Pre-IFRS period, the discretionary accrual ranges from 0.0049 to 0.173 , with a mean of 0.000154 and a standard deviation of 0.0012 . The earnings per share varies from (N542.93) to N2019, with a mean of N93.37 and a standard deviation of N227.5. The book value of equity per share varies from (N49.9) to N23.45, with a mean of N0.05 and a standard deviation of $\mathrm{N} 3.47$, while the share price has a minimum of N0.20 and a maximum of N445.6, with a mean of N26.66 and a standard deviation of N54.63.

The Post-IFRS discretionary accruals varies from -0.0065 to 0.0143 , with a mean of 0.000109 and a standard deviation of 0.00105 . The earnings per share gives a minimum of (N2076) and a maximum of N4011.87, with a mean of N92.12 and a standard deviation N360.04, book value of equity ranged from

(N16.22) to N180.45, with a mean of N0.98 and a standard deviation of $\mathrm{N} 10.73$. The share price shows a range between N0.50 and N1200, with a mean of N38.80 and standard deviation of N127.03. It should be noted that there are large differences between minimum and maximum values, means and standard deviation also varies noticeably. However, the mean of discretionary accruals, earnings per share, book value per share and market share price went in mixed directions from the pre-adoption to the post-adoption period. Two core findings from the above descriptive statistics is that the mean discretionary accruals fell in the post-IFRS period showing early signs of a reduction in earnings management as a result of adopting IFRS, while share prices increased in the postadoption period showing early signs of an increase in value relevance as a result of IFRS adoption.

\subsection{Pearson's Correlation Technique}

Table 4.2 Pearson Correlation Matrix

PRE-IFRS

\begin{tabular}{|c|c|c|c|c|}
\hline & & SP PRE IFRS & BV PRE IFRS & EPS PRE IFRS \\
\hline SP PRE IFRS & Pearson Correlation & 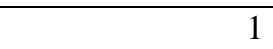 & $.362^{* * *}$ & $.428^{* * *}$ \\
\hline & Sig. (2-tailed) & & .000 & .000 \\
\hline & $\mathrm{N}$ & 300 & 300 & 300 \\
\hline BV PRE IFRS & Pearson Correlation & $.362^{* * *}$ & 1 & $.141^{*}$ \\
\hline & Sig. (2-tailed) & .000 & & .014 \\
\hline & $\mathrm{N}$ & 300 & 300 & 300 \\
\hline EPS PRE IFRS & Pearson Correlation & $.428^{* *}$ & $.141^{*}$ & 1 \\
\hline & Sig. (2-tailed) & .000 & .014 & \\
\hline & $\mathrm{N}$ & 300 & 300 & 300 \\
\hline
\end{tabular}

\begin{tabular}{|l|l|r|r|r|}
\hline \multicolumn{2}{|c|}{} & SP PRE IFRS & BV PRE IFRS & EPS PRE IFRS \\
\hline SP PRE IFRS & Pearson Correlation & 1 & $.470^{* *}$ & $.457^{* *}$ \\
& Sig. (2-tailed) & 300 & .000 & 300 \\
& $\mathrm{~N}$ & .000 & 300 \\
\hline BV PRE IFRS & Pearson Correlation & .000 & 1 & $.285^{* * *}$ \\
& Sig. (2-tailed) & 300 & .000 \\
& $\mathrm{~N}$ & $.457^{* *}$ & 300 \\
\hline EPS PRE IFRS & Pearson Correlation & .000 & $.285^{* *}$ & .000 \\
& Sig. (2-tailed) & 300 & 300 & 1 \\
& $\mathrm{~N}$ & & 300 \\
\hline
\end{tabular}

\section{Source: SPSS Output, 2018}

**. Correlation is significant at the 0.01 level (2-tailed). *. Correlation is significant at the 0.05 level (2-tailed).

Table 4.2 shows the Pearson correlation result in the pre-IFRS era shows a positive and moderately significant relationship between share prices and book value of equity per share $(\mathrm{r}=0.362$ and $\mathrm{p}=0.00)$. The table also reveals there is a positive and significant relationship between share prices and earnings per share $(r=0.428$ and $\mathrm{p}=0.000)$. In the post-IFRS era, the result shows a positive and moderately significant relationship between share prices and book value of equity per share $(\mathrm{r}=0.470$ and $\mathrm{p}=0.000)$. The table also reveals there is a positive and weak but significant relationship between share prices and earnings per share $(\mathrm{r}=0.285$ and $\mathrm{p}=0.000)$. 


\subsection{Panel Data Regression}

Table 4.3.1 Panel Data Regression (Value Relevance)

\begin{tabular}{|c|c|c|c|c|c|c|c|}
\hline \multicolumn{4}{|c|}{ Pre-IFRS } & \multicolumn{4}{|c|}{ Post-IFRS } \\
\hline $\begin{array}{l}\text { Dependent Var } \\
\text { ANOVA: }\end{array}$ & $\begin{array}{c}\text { iable - SharePric } \\
\text { Mean Square } \\
115.098\end{array}$ & $\begin{array}{l}\text { F-stat } \\
56.566 \\
\end{array}$ & $\begin{array}{l}\text { P-value } \\
0.000\end{array}$ & $\begin{array}{l}\text { Dependent Var } \\
\text { ANOVA: }\end{array}$ & $\begin{array}{l}\text { riable - SharePrice } \\
\text { Mean Square } \\
172.715 \\
\end{array}$ & $\begin{array}{l}\text { F-stat } \\
74.526 \\
\end{array}$ & $\begin{array}{l}\text { P-value } \\
0.000 \\
\end{array}$ \\
\hline Variable & Coefficients & t-stat & P-value & Variable & Coefficients & t-stat & P-value \\
\hline $\mathrm{C}$ & 2.363 & 10.280 & 0.000 & $\mathrm{C}$ & 2.640 & 10.812 & 0.000 \\
\hline BVit & 0.246 & 7.702 & 0.000 & BVit & 0.340 & 7.477 & 0.000 \\
\hline $\begin{array}{l}\text { EPS } \\
\text { Observation } \\
\mathbf{s} \\
\end{array}$ & $\begin{array}{l}0.270 \\
300\end{array}$ & 6.174 & 0.000 & $\begin{array}{l}\text { EPS } \\
\text { Observations }\end{array}$ & $\begin{array}{l}0.252 \\
300\end{array}$ & 7.119 & 0.000 \\
\hline $\begin{array}{l}\text { Adj. R- } \\
\text { Squared- }\end{array}$ & 0.271 & & & $\begin{array}{l}\text { Adj. R- } \\
\text { Squared- }\end{array}$ & 0.430 & & \\
\hline
\end{tabular}

Source-Author's compilation (Estimated with SPSS 20)

Table 4.3.1 shows the panel data regression estimation results for the effect of IFRS on value relevance in both the Pre and Post IFRS periods. From the result, the adjusted R-Squared in the pre-adoption era is 0.271 implying that the model is able to explain $27.1 \%$ of the systematic variations in share price. However, the essence of this estimation is to compare the adjusted R-squared in both eras so as to ascertain the effect of IFRS adoption on value relevance in Nigerian firms. In light of the foregoing, we can observe from the table that the adjusted R-squared in the post-adoption era is $43 \%$ (a $\mathbf{5 6 . 8 \%}$ increase from the pre-adoption period), this implies that the mandatory adoption of IFRS has led to increased value relevance in Nigeria. Also, although the ANOVA section of the table reveals significant F-statistic and P-values in both eras, the mean square in the post-IFRS era (172.715) is higher than that of the pre-IFRS era (115.098). Firstly, this shows a significant difference in both eras and also shows a significant influence on value relevance level in Nigeria after the mandatory IFRS adoption (Post-IFRS).

Observing the coefficients in both eras also show that book value and earnings per share both exert a positive influence on share price as suggested by the model. The individual test of significance as shown by the t-test also reveals that the variables remained statistically significant in both the pre and post-adoption periods.

The study will then proceed to ascertain the influence of IFRS on earnings management by using the paired samples technique in the table below.

\section{Table 4.3.2 Paired Sample t-test (Earnings Management)}

\section{a. Paired Samples Correlations}

\begin{tabular}{|c|c|c|c|c|}
\hline & & $\mathrm{N}$ & Correlation & Sig. \\
\hline Pair 1 & DA PRE IFRS \& DA POST IFRS & 300 & -.119 & .047 \\
\hline
\end{tabular}

b. Paired Samples Test

\begin{tabular}{|c|c|c|c|c|c|c|c|c|}
\hline & \multicolumn{5}{|c|}{ Paired Differences } & \multirow[b]{3}{*}{ t } & \multirow[b]{3}{*}{$\mathrm{df}$} & \multirow{3}{*}{$\begin{array}{l}\text { Sig. }(2- \\
\text { tailed) }\end{array}$} \\
\hline & \multirow[b]{2}{*}{ Mean } & \multirow{2}{*}{$\begin{array}{c}\text { Std. } \\
\text { Deviation }\end{array}$} & \multirow{2}{*}{$\begin{array}{l}\text { Std. Error } \\
\text { Mean }\end{array}$} & \multicolumn{2}{|c|}{$\begin{array}{l}95 \% \text { Confidence Interval of } \\
\text { the Difference }\end{array}$} & & & \\
\hline & & & & Lower & Upper & & & \\
\hline $\begin{array}{l}\text { DA PRE IFRS - } \\
\text { DA POST IFRS }\end{array}$ & -1.788 & 1.077 & .077 & -1.963 & 1.939 & -13.33 & 299 & .000 \\
\hline
\end{tabular}

Source: SPSS Output, 2017

From Table 4.32a and $b$ above, we have conducted a paired sample t-test using data from discretionary accruals to ascertain the effect of IFRS adoption on earnings management using discretionary accruals in both the pre and post-IFRS eras. For the discretionary accruals variable, the result obtained from our analysis presented in the tables above yielded a mean value of -1.788 with a t-test statistic of -13.33 and a P-value of 0.000 which is statistically significant. This implies that there is a significant difference between the pre and post IFRS adoption level of earnings management in Nigeria. Additionally, the negative value of the mean suggests that discretionary accruals are lower in the post-adoption period. We can therefore infer that the mandatory adoption of IFRS has led to reduced earnings management practices in 
Nigeria.

\subsection{SUMMARY OF FINDINGS, CONCLUSION AND RECOMMENDATIONS}

The primary purpose of this study is to empirically examine Earnings Management and Value Relevance in Nigeria, using a Pre and Post IFRS Analysis. From the analysis in the previous section, the preliminary descriptive statistics, using the mean values of discretionary accruals and share prices respectively, suggested that the mandatory adoption of IFRS in Nigeria has led to reduced earnings management as well as increase in value relevance of firms. The Pearson's correlation matrix revealed a positive interrelationship amongst the variables.

This was further emphasized in the panel data regression where both the earnings per share and book value were seen to have positive and significant impacts on share price in both the pre and post adoption periods. From the regression result, it is seen that the adjusted R-squared in the post-IFRS era (43\%) was higher than that in the pre-IFRS era (27.1\%), this provides conclusive evidence that adopting IFRS has increased value relevance in Nigerian firms. Alternatively, the paired samples test revealed that discretionary accruals were in fact lower in the post-adoption period, thereby suggesting that that the adoption of IFRS has lowered earnings management in Nigerian firms.

These findings are a massive boost to literature in this area because it provides clarity and closure in the midst of uncertainties and mixed results. As a result, this study proffers the following recommendations;

i. Nigeria's regulatory and legal agencies should set up policies to check the essences of management of companies and effectively implement same in order to ensure investors' protection from opportunistic managers.

ii. The relevant regulatory bodies should be empowered by the government to enable the formulation of effective measures and policies in order to foster value relevance of the financial information presented in the annual reports and accounts of Nigerian companies.

Effective corporate governance mechanisms aimed at tackling unrevealing sharp managerial practices should be implemented.

In order to uphold the codes of ethics guarding the Accounting as well as the Auditing profession, there is need for compulsory rotation of auditors in their audit engagement.

Accounting Standards Setting Bodies should encourage public enlightenment programmes for fresh graduates, practicing Accountants and managements to ensure that they are fully abreast with IFRS accounting standards. Thus, encouraging their application in financial reporting and analysis to enhance quality, transparency, comparability, and relevance and reliance financial information. The following recommendations for further studies are suggested:

The study examined 60 non-financial companies listed in the Nigerian Stock Exchange from 2007 to 2016. Future studies could focus on more companies listed in the second-tier and emerging market of the Nigerian Stock Exchange.
The study focuses on a period of ten (10) years covering 2007 to 2016. Future studies should consider a wider scope that also should include the 2015-2017 recession and economic growth periods in Nigeria.

As a result of the fact that there are other models of earnings management and value relevance as well as other predicator variables, future studies could include such variables and predictor variables.

\section{REFERENCES}

[1] Adaramola, A.O. \& Oyerinde, A. A. (2014). Value relevance of financial accounting information of quoted companies in Nigeria: A trend analysis. Research Journal of Finance and Accounting, 5(8), 86-93.

[2] Adebimpe, O. U \& Ekwere, R. E. (2015). IFRS adoption and value relevance of financial statement of Nigeria listed banks. International Journal of Finance and Accounting, 4 (1), 1-7.

[3] Adekoya, O. (2011). Similarities and differences, IFRS and Nigeria GAAP. Lagos: Price Water House Coopers International Limited (PNCIL).

[4] Agbonifoh, B. A. \& Yomere, G. O. (1999). Research Methodology in the Management and Social Sciences (1st Ed.). Benin City: Uniben Press.

[5] Ahmed, A. (2011). Practical challenges of IFRS implementation: "What Bank Regulators Need to Know". IFRS International Conference Nigeria.

[6] Ashbaugh, H., LaFond, R. \& Mayhew, B.W. (2003). Do Non-audit Services Compromise Auditor Independence? Further Evidence. Accounting Review, 78, 611-639.

[7] Ball, R. \& Brown, P. (1968). An empirical evaluation of accounting income numbers. Journal of Accounting Research, 6(2), 159-178.

[8] Barth, M. E., Landsman, W. R. \& Lang, M. H. (2008). International Accounting Standards and Accounting Quality. Journal of Accounting Research, 46, 467-498.

[9] Barth, M.E., Beaver, W. H. \& Landsman M. (2001). The relevance of the value relevance literature of financial accounting standards setting: another view. Journal of Accounting and Economics, 31, 77-104.

[10] Bartov, E., Goldberg, S. R., \& Kim, M. (2005). Comparative value relevance among German, U.S., and international accounting standards: a German stock market perspective. Journal ofAccounting, Auditing \& Finance, 20 (2), 95-119.

[11]Beneish, M. (2001). Earnings management: A perspective. Managerial Finance, 27(12): 3-1.

[12] Bhattacharjee, S., \& Hossain, M. S. (2010). Determinants of financial reporting outcomes following IFRS adoptionimplications for Bangladesh. [Online] Available: http://www.icab.org.bd/journal/61.pdf

[13] Cai, L. Rahman, A. \& Courtenay, S., (2008). The Effect of IFRS and its Enforcement on Earnings Management: An International Comparison. Social Science Research Network. Available at: http://ssrn.com/abstract $=1473571$

[14]Callao, S. \& Jarne, J. I. (2010), "Have IFRS affected earnings management in the European Union?" 
Accounting in Europe, 7 (2), 159-189.

[15] Callao, S., Jarne, J., \& Larnez, A. (2007). Adoption of IFRS in Spain: effect on the comparability and relevance of financial reporting. Journal of International Accounting, Auditing and Taxation, 16, 148-178.

[16] Capkun, V., A. Cazavan-Jeny, T. Jeanjean\& L. A. Weiss. (2008). Earnings management and value relevance during the mandatory transition from local GAAP to IFRS in Europe. Working Paper.

[17] Christensen, H. B., E. Lee, \& M. Walker (2008). "Incentives or standards: What determines accounting quality changes around IFRS adoption?" Financial Accounting and Reporting Section (FARS) Paper, the American Accounting Association.

[18] Chunhui. L., Yao, L. J., Lee J., Hu N. \& Liu, L. (2011). The impact of IFRS on accounting quality in a regulated market: An empirical study of China. Journal of Accounting, Auditing and Finance, 26, 659-676.

[19] Clarkson, P., Hanna, J. D., Richardson, G. \& Thompson, R. (2011). The impact of IFRS adoption on the value relevance of book value and earnings. Journal of Contemporary Accounting \& Economics, 7, 1-17.

[20] Eisenhardt, K. M. (1989). Agency theory: An assessment and review. Academy of Management Review, 14(1), 5774.

[21] Elias, N. (2012). The impact of mandatory IFRS adoption on accounting quality: Evidence from Australia. Journal of International Accounting Research, 11, 147-154.

[22] Fama, E., \& Jensen, M. (1983). Separation of ownership and control. Journal of Law and Economics, 26, 301-326.

[23] Fields, T., Lys, T. \& Vincent. L. (2001). "Empirical research on accounting choice". Journal of Accounting and Economics, 31, 255-307

[24] Gaston, S., García, C., Jarne, J. \&Gadea, J. (2010). IFRS adoption in Spain and the United Kingdom: Effects on accounting numbers and relevance. Advances in Accounting, incorporating Advances in International Accounting, 26,304-313.

[25] Healy, M. P., \& Wahlen, M. J. (1999). A review of the earnings management literature and its implications for standard setting. Accounting Horizons, 13(4), 365-383.

[26] Healy, P. M. (1985). The effect of bonus schemes on accounting decisions. Journal of Accounting and Economics, 7, 85-107.

[27] Hellstrom, K. (2009). Financial quality in a European transition economy: the case of the Czech Republic. Stockholm: The Economic Research Institute. Retrieved from http://www.hhs.se/efi.

[28] IASB (2010): The Conceptual Framework for Financial Reporting 2010. London.

[29] IFRS Frequently Asked Questions developed by American Institute of Certified Public Accountants (AICPA). Retrieved from www.IFRS.com/ifrs faqs.html on 11th August, 2017.

[30] Jeanjean, T. \& Stolowy, H. (2008). Do accounting standards matter? An exploratory analysis of earnings management before and after IFRS adoption. Journal of
Accounting and public policy, 27 (1), 480-494.

[31] Jensen, M. \& Meckling, W. (1976). 'Theory of the firm: Managerial behavior, agency costs and ownership structure.' Journal of Financial Economics, 3 (4), 305360.

[32] Jinadu, O. (2016). The Adoption of IFRS and Value Relevance of Accounting Information in Nigeria. International Journal of Innovative Research and Advanced Studies (IJIRAS), 3(4).

[33] Jones, J. J. (1991). Earnings management during import relief investigations. Journal of Accounting Research, 29(2), 193-228.

[34] Kaaya, I. D. (2015). The International Financial Reporting Standards (IFRS) and Value Relevance: A Review of Empirical Evidence. Journal of Finance and Accounting, 3(3), 37-46. Available online at http://pubs.sciepub.com/jfa/3/3/1.

[35] Kamath. R., and Desai, R. (2014). The Impact of IFRS adoption on the financial activities of companies in India: An empirical study. The IUP Journal of Accounting Research and Audit Practices, 13: 25-36.

[36] Kargin, S. (2013). The impact of IFRS on the value relevance accounting information: Evidence from Turkish firms. International Journal of Economy and Finance, 5(4), 71-80.

[37] Li, J. \& Park, S.K. (2012), "Earnings management effects of IFRS adoption and ownership structure: evidence from China", Korea International Accounting Review, 41, 121136.

[38] Luz, P. T. (2013). Earnings Management under IFRS and PGC. Revista de ComptabilitatiDirecció, 16, 161-185.

[39] McKee, T. E. (2005). "Earnings Management: An Executive Perspective". Mason, $\mathrm{OH}$ : Thomson Higher Education

[40] Mousa, G. A. \& Desoky, A. M. (2014). The value relevance of IFRS: the case of the GCC countires. Journal of Accounting, Finance and Economics, 4(2), 16-28.

[41] Musa, A. F \&Shehu, U. H. (2014). Impact of audit quality and financial performance of quoted cements firms in Nigeria. International journal of accounting and taxation, 2(2), 1- 22.

[42] Napaporn, L. \&Siriluck, S. (2015). Does IFRS adoption mitigate accrual earnings management? Evidence from an emerging market. UTCC International Journal of Business \& Economics, 7(2), 49-72.

[43] Neuman, W. L. (2004). Basics of social research: Qualitative and quantitative approaches, Boston, Mass, Pearson.

[44] Ohlson, J.A. (1995). Earnings, Book Values and Dividends in Security Valuation. Contemporary Accounting Research, 11(1), 661-688.

[45] Olayinka, M. U. (2012). Earnings management and corporate governance in Nigeria. Research Journal for Finance and Accounting, 3(3). ISSN 2222-1697 (Paper) ISSN 2222-2847 (Online). 
[46] Omokhudu, O. O. \&Ibadin, P. O. (2015). The Value Relevance of Accounting Information: Evidence from Nigeria. Accounting and Finance Research, 4 (3), 20-30.

[47] Paananen, M. (2008): 'The IFRS adoption's effect on accounting quality in Sweden'. SSRN Working paper series: http://ssrn.com/abstract=1097659.

[48] Rudra, T. \& Bhattacharjee, D. (2012). "Does IFRSs influence earnings management? Evidence from India". Journal of Management Research, 4 (1), 1-13.

[49] Schipper, K. (1989). Commentary on earnings management. Accounting Horizon, 3(1), 91-102.

[50] Tsalavoutas, I., Andre, P. \& Evans L. (2012): 'The transition to IFRS and the value relevance of financial statements in Greece'. British Accounting Review, 44 (4), 262-277.

[51] Umoren, A. O. \& Enang, E. R. (2015). IFRS adoption and value relevance of financial statement of Nigerian listed banks. International Journal of Finance and Accounting, (4), 1-7.

[52] Vijitha, P. \&Nimalathasan, B. (2013). Value relevance of accounting information and share price: A study of listed manufacturing companies in Sri Lanka. Merit Research Journal of Business and Management, 2(1), 001-006.

[53] Vishnani, S. \& Shah, B. (2008). International differences in the relation between financial Reporting Decisions and Value Relevance of Published Financial Statements- with Special Emphasis on Impact of Cash Flow Reporting, International Research Journal of Finance and Economics, 17(1), 1450-2887.

[54] Yahaya, O. A., Kutigi, U. M. \& Mohammed, A. (2015). International Financial Reporting Standards and Earnings Management Behaviour of Listed Deposit Money Banks in Nigeria. European Journal of Business and Management, 7 (18). ISSN 2222-1905 (Paper) ISSN 2222-2839 (Online). 